Revista Española de Antropología Americana

ISSN: 0556-6533

\title{
A Syllabic Sign for [pe] in the Classic Maya Inscriptions
}

\author{
Albert Davletshin ${ }^{1}$ y Dmitri Beliaev ${ }^{2}$
}

Recibido: 30 de abril de 2021 / Aceptado: 15 de mayo de 2021

\begin{abstract}
The paper is dedicated to the "Rabbit Head" sign in Maya hieroglyphic writing. It is possible to establish its phonetic reading value pe thanks to two observations - the sign is optionally combined with the syllable ' $e$ in the name of La Mar kingdom and bears resemblance to Diego de Landa's sign for the letter "p". This syllabic value pe results in the reading of La Mar as pe[pe] 'tuun and identification of two verbal roots: pek- "to summon, call up" and kop- "to roll up, coil". The former one is used to describe convocation of the subjects before the king and invoke gods. The word ' $u$-kope ' $m$ " his rolledup one" is a term for "bloodletting rope", also used as part of a metaphorical "father's child" parentage statement.
\end{abstract}

Keywords: Maya; Classic Maya; hieroglyphic writing; epigraphy; decipherment.

\section{[es] Un signo silábico para [pe] en las inscripciones clásicas mayas}

Resumen. El artículo está dedicado a la lectura fonética del signo "cabeza de conejo" en la escritura jeroglífica maya del período Clásico. Se pudo identificar su valor como la sílaba pe gracias a dos observaciones: el signo se combina con el silabograma 'e en el nombre del reino de La Mar y se parece a la letra "p" del alfabeto de Diego de Landa. Este valor silábico pe resulta en la lectura del nombre de La Mar como pe[pe] 'tuun así como en la identificación de dos raíces verbales: kop- "rollar, enroscarse" y pek- "llamar, invocar". La última se utiliza para describir la convocatoria de vasallos frente a su rey o cuando se invoca a los dioses. La palabra ' $u$-kope ' $m$ "su cosa enrollada" se utiliza como el término para "la cuerda del sacrificio de sangre", además, ésta forma parte de una expresión metafórica de parentesco "el hijo del padre".

Palabras clave: mayas; período Clásico; escritura jeroglífica; epigrafía; desciframiento.

Contents. 1. Introduction. 2. Syllabogram pe in the Postclassic Texts. 3. Syllabogram pe in the Classic Texts. 4. Broader implications. 5. References.

How to cite: Davletshin Albert y Beliaev Dmitri. 2022. "A Syllabic Sign for [pe] in the Classic Maya Inscriptions". Revista Española de Antropología Americana 52 (1): 29-43.

1 Institute for Oriental and Classical Studies, Russian State University for the Humanities, Moscow. International Center of Anthropology of the National Research University Higher School of Economics, Moscow. aldavletshin@mail.ru.

2 Knorozov Center for Mesoamerican Studies, Russian State University for the Humanities, Moscow. International Center of Anthropology of the National Research University Higher School of Economics, Moscow. Institute of Ethnology and Anthropology, Russian Academy of Sciences, Moscow. lakamha@mail.ru. 


\section{Introduction}

The significance of Amerindian societies for anthropological theory can hardly be overestimated because they independently developed complex political institutions, states, bureaucracies, cities, market economies, agriculture and writing. Yet Maya hieroglyphic texts hold a very special place in this respect because they represent the only extensive corpus of written sources, which significantly predate the arrival of Europeans and can be read in the literal sense of the word. This however means that our understanding of Maya societies significantly depends on our understanding of Maya hieroglyphic writing system.

In recent years, Maya epigraphy has been steadily witnessing interest in the methods of decipherment. Here, decipherment should be understood as establishing reading values of individual signs. The widely accepted phonetic approach was heralded by Yuri Knorozov in his seminal paper "Writing of the Indians of Central America" (Knorozov 1952). Nevertheless, several positions in the syllabic grid have yet to be filled in. Some scholars state that Maya hieroglyphic writing is "not yet completely deciphered" or "semi-deciphered" (Diehr et al. 2018: 33), despite the fact that all the deciphered scripts enjoy a certain amount of the signs with unknown phonetic readings. Christian Prager (2021: 101) estimates that about 30\% of approximately one thousand Maya signs cannot be read. This view contrasts with the evaluation of Maya epigraphy as "mature discipline" (Houston and Martin 2016; see also Matsumoto and Carter 2020). The number of phonetic decipherments has been constantly increasing. Recently, Marc Zender and his coauthors have presented "an apologia for delayed decipherment" looking for explanations why it took so long for certain signs to be read (Zender et al. 2016; Zender 2017). It can be observed that the syllabic signs of the shape $\mathrm{Ce}$ and $\mathrm{Co}$ are relatively rare, in particular, in word-final position. Here, C stands for any consonant. This observation explains why most unfilled positions in the Maya syllabic grid feature either $e$ or $o$ vowels and it might be explained by the fact that the $\mathrm{Ci}, \mathrm{Ca}$, and $\mathrm{Cu}$ signs but not $\mathrm{Ce}$ and $\mathrm{Co}$ are employed to indicate vowel complexity (Houston et al. 1998; Lacadena and Wichmann 2004). Because of the same reason, $\mathrm{Ce}$ and Co syllables have a strong tendency to congregate with syllabic signs and logographs with which they share vowel quality; this fact facilitates their recognition among undeciphered signs (Stuart 2008; cf. Zender et al. 2016: 39).

In this paper, we present evidence for interpreting the "Rabbit Head" sign of the Classic period (AD 250-900) as the syllable pe. The arguments in favor of this reading were originally circulated via e-mail to fellow epigraphers in 2001 but have been never properly published.

We first consider evidence for the syllabic reading pe of the "Rabbit Head" sign in the Postclassic codices, then we examine Classic examples of the sign under consideration and, finally, we discuss some implications of this decipherment for a better understanding of Classic Maya society.

\section{Syllabogram pe in the Postclassic Texts}

In his "alphabet", Diego de Landa gives a sign for the letter "p" (Figure 1a). Its Postclassic and Late Classic equivalents (Figure 1b-c) depict a rabbit head characterized by a distinct whisker-like ruff, dotted fore-muzzle and long ear bearing 
an X draped atop the head (cf. Stone and Zender 2011: 199). This X pattern is also attested on water-lily pads, turtle carapaces, flints and in a Postclassic logograph of unknown reading (Figure 1d). The meaning of the X pattern is unclear; Elisabeth Wagner has suggested to us that it may refer to visible veins of rabbit ears (personal communication, 2017). Yuri Knorozov read this sign as pek' "dog" and identified it with number 801 in the Thompson catalog - T801 (Thompson 1962; Knorozov and Ershova 1994: 29). Victoria Bricker has also suggested that Landa's "p" represented a logographic sign PEK" "dog" and correctly identified it as T759 (Bricker 1986: 155156). She was the first to read the glyphic collocation T759:25.181 in the Dresden Codex (D4a-D10a, D4b-D5b) as pekah and connect it to the widespread Lowland Mayan root pek- "to sound".

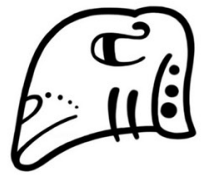

a

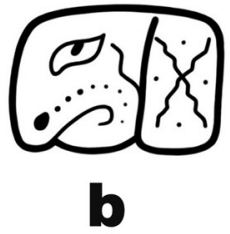

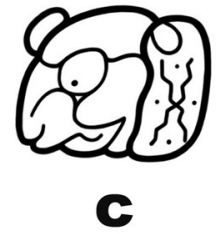

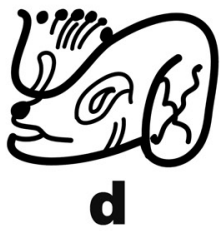

Figure 1. The pe syllable in the Maya script: a) Landa's "p"; b) Postclassic Period variant of the pe syllable (T759b); c) Classic Period variant (T759a); d) Postclassic Period sign depicting an animal head with an X pattern (D47). Drawings by Albert Davletshin and Philippe Galeev.

The verb was interpreted as pekah "it was read" by Werner Nahm who was first to suggest that T759b is a pe syllable (cited in Schele and Grube 1997: 96-97). Nikolai Grube compared pe-ka-ha with the corresponding Ch'ol gloss and translated pekah tu chich as "es wurde laut in dem Schicksal gelesen/(his) fate was proclaimed" (Grube 1998: 93). Kerry Hull connected the stem pek- to Ch'orti ' pekaj meaning, in ritual speech, "to invoke spirits", and, in common usage, "to speak, call, invite, notify". He proposed the reading pe-ka-ja K'UH, pe-ka-ja ITZ-AM-na, "was invoked the god, was invoked Itzamnaaj" for D4b.1-2 and pe-ka-ja tu-chi-chi (god's name) "he was invoked, by his prophecy, God XXX" for D4a.1-D10a.2 (Hull 2000: 17).

There are other glyphic spellings in Postclassic Maya codices which involve the "Rabbit Head" sign: 'u-pe? (D14), CHAK-pe? (D46, D47) and NUMBER-pe?NAL (D39c, D40c, D44a, see also P7c and D41c). It is possible to interpret these glyphic compounds basing on the reading pe and lexical entries from various Mayan dictionaries. However, we desist from any suggestions in these cases because they lack semantic control.

\footnotetext{
We use the widely established orthography to represent the data from Mayan languages, which is a version of American Phonetic Alphabet. The symbols that differ from the International Phonetic Alphabet symbols are the following: $\mathrm{VV}=$ long vowel, $\mathrm{C}^{\prime}=$ glottalized consonant, ${ }^{\prime}=/ \mathrm{P} /, \mathrm{b}{ }^{\prime}=/ \mathrm{b} /, \mathrm{x}=/ \mathrm{J} / \mathrm{tz}=/ \mathrm{ts} /, \mathrm{ch}=/ \mathrm{f} /, \mathrm{y}=/ \mathrm{j} /$, and $\mathrm{j}=/ \mathrm{x} /$. The lexical entries from Colonial sources are not highly reliable with respect to transcription; in accordance with the established practice, this is indicated by surrounding them with angle brackets " $<$... $>$ ". We follow the interpretation of synharmonic and disharmonic spellings proposed by Alfonso Lacadena and Søren Wichmann $(2004,2019)$. Citing other authors, we preserve their interpretations but unify orthographies, so Victoria Bricker's "pec-ah" is given as pekah here and transcribed as pehkaj below.
} 
To sum up, the reading pe for the "Rabbit Head" sign in the codices is well recognized and widely accepted. However, cross-readings for the sign under discussion in Postclassic codices are lacking and this fact makes the identification of its phonetic reading problematic.

\section{Syllabogram pe in the Classic Texts}

a

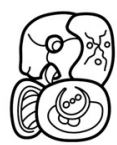

b

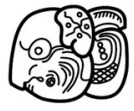

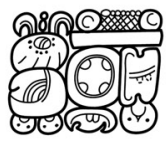

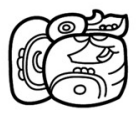

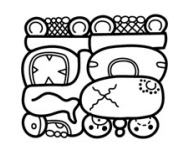
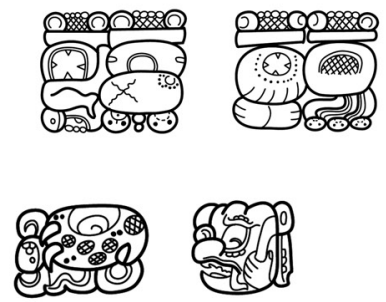
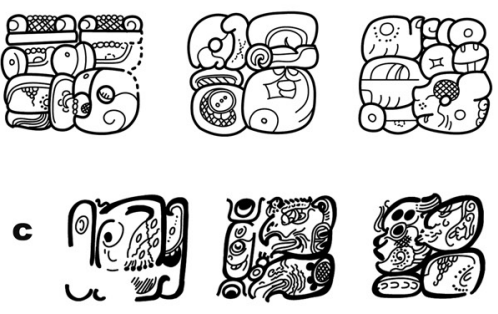

Figure 2. The spelling "Rabbit"-ka-ja: a) passage from the text on the Saktz' $i^{6}$ panel from the Royal Art Museum in Brussels; b) passage on La Corona Element 56; c) passage on the Mural of the 96 Glyphs at Ek Balam. Drawings by Albert Davletshin: (a) after photographs by the authors, (b) after photographs of the "Atlas Epigráfico de Petén" Project, (c) after drawings by Alfonso Lacadena.

Sign T759a is a Classic-period version of Postclassic T759b. It also depicts a mammal with X-marked ears and it is also used as a part of the collocation "Rabbit Head"-ka-ja. One example of the sign appears on the panel of unknown provenance housed in the Royal Art Museum in Brussels (Figure 2a). This was part of a larger monument, probably a wall panel. Its protagonist is $K^{\prime} a b^{\prime}$ Chante $^{6}$, a lord of Saktz' $i^{\prime}$, which was a polity centered at the site of Lacanja Tzeltal on the left bank of the Usumasinta river (Golden et al. 2020). The sign in question appears twice in the collocation "Rabbit Head"-ka-ja and represents a verb in the passive voice ...h-k$a j-\varnothing$ (on the passive form see Bricker 1986: 128-129, 138; Lacadena 2004: 165-179). The inscription tells us about a war between Saktz' $i^{\prime}$ on one side, and La Mar and 'Ak'e' on the other. On the day 3 Chikchan (probably, 9.13.1.1.5 8 Sip, April 4, 693), $K^{\prime}$ 'ab'Chante 'captured the $A k^{\prime}$ ' $e^{\text {' }}$ king $J u^{\prime} n M a y M o^{6}$, he was accompanied by a local lord Yab' $a . . . l$ from $K$ 'ante 'l. The glyphic collocation "Rabbit Head"-ka-ja closes the text and enlists several secondary rulers from the Middle Usumacinta area: (pD5) "Rabbit Head"-ka-ja (pC6) ya-b'a-...-la 'a-K'AN-TE'-la (pD6) 'a-K'IN-YA'(?)'a 'a-CHAK-TOK'-la (pC7) 'a-?-su 'a-pa-ni-la (pD7) 'a-'a-TUN-ni 'a-'a-b'b'u-'a (pC8) 'Rabbit Head"-ka-ja yi-chi-NAL (pD8) k'a-b'a-CHAN-TE' SAK-TZ'I''AJAW'.

The use of the "Rabbit Head" sign in this context was analyzed by Dieter Dütting and Nikolai Grube (cited after Dütting and Johnson 1993: 187-191). They observed the substitution of T759 for T580:59 and T580:103 and suggested the reading loh.ka-h(a),

4 The transliteration, transcription and translation of the text here differ from the published previously (Beliaev 2004: 129). Some emendations were made during the $18^{\text {th }}$ European Maya Conference in Brussels in 2013 when the authors could personally examine the monument. 
"the freeing began" because T580 was read lo in those times (Dütting and Johnson 1993: 189-190). Later, Linda Schele connected the verb under discussion with the Venus because it is recorded at Copan associated with Venus deities, on the date which coincides with heliacal rising of Evening Star (Schele and Grube 1995: 108).

The syllabic value pe for the "Rabbit Head" sign gives us the reading pehkaj "he was/they were called", which makes more sense in the context. The passage starts with the sentence which can be transcribed and translated as follows: pehkaj Yab'a...l 'Aj-K'ante'l 'Aj-K'inya' 'Aj-Chakto 'k'al 'Aj-...S 'Aj-Paniil 'Aj-'Atuun 'Aj'Ab'u 'a 'pehkaj y-ichnal K'ab'Chante' Saktz'i' 'ajaw, "such and such persons were called'. The passage is closed by the sentence: pehkaj y-ichnal K'ab'Chante 'Saktz' $i$ ' 'ajaw, "they were called before $K$ 'ab' Chante", the king of Saktz' $i$ ". Several "titles of origins" (Stuart and Houston 1994: 33-42) are mentioned; these are derived from the corresponding place-names: K'ante'l ("Place where the tree madre de cacao abounds"), K'ihnya ' (the reading and its interpretation are problematic), Chakto'k'al ("Place where Red Flint abounds"), ...s (the reading is unclear), Paniil ("Place where the Toucan abounds"), "Atuun (the reading and its interpretation are problematic), and ' $A b^{\prime} u^{\prime}$ ' $a$ ' (the reading and its interpretation are problematic). This passage was previously interpreted as a list of local lords, who ruled over secondary towns of the 'Ak' $e$ ' kingdom (Beliaev and Safronov 2004: 124). However, an alternative explanation is possible (see below).

Another example of "Rabbit Head"-ka-ja appears on Sculptured Stone 5 from Bonampak: (H6) 5-KIB' (H7) 9-K'AN-JAL-wa (H8) pe-ka-ja (H9) hu-chi' ${ }^{5}$ (I1) ch'a-jo-ma-'a-na-b'i (J1) yi-ta-ji (K1) 'AJ-'USIJ+WITZ (L1) ta-YAXUNB'ALAM-ma (M1) $\mathbf{P A}^{6}+\mathbf{C H A N + ' A J A W , ~ h o ' ~ K i b ' ~ b ' o l o ' n ~ K ' a n j a l a w ~ p e h k a j ~}$ Huuch ch'ajo ' $m$ 'a'naab'y-itaaj 'Aj 'Usiij Witz ta Yaxuun B'ahlam Pa'chan 'ajaw, "on the day $5 \mathrm{Kib}$ ' the $9^{\text {th }}$ day of the month Pop, the incense scatterer and portraitist Huuch, and the person from Bonampak were called by Yaxuun B'ahlam, the king of Yaxchilan".

The verb under discussion (Figure 2b) is also attested on the panel from La Corona discovered in 2013 (see Element 56 in Stuart et al. 2015). The text is dated to 9.12.16.12.9 13 Muluk 17 Muwan (December 10, 688): pe-ka-ja yi-chi-NAL yu-ku'ICH'AK-K'AK' KALOM-TE', pehkaj y-ichnal Yuhk[no 'm] Yihch'aahk K'ahk' kalo 'mte", "he was convoked before the overlord Yukno 'm Yihch'aak K'ahk". This convocation took place four days after another event of unknown nature, in which the local lord Chak 'Ak' Paat Kuy had participated (Houston et al. 2017).

Another example of the collocation (Figure 2c) is attested on the Mural of the 96 Glyphs at Ek Balam in Northern Yucatan (Lacadena 2003: 50, Figs. 18b-c). It mentions the arrival of ' $U$ Kan Tzimaah at Ek' Balam. This mention is followed by the phrase 'u-pe-ka-ja 'u-ki-ti ka-na-le-ku, 'u-pekaj 'Ukit Kan Le' $k$. Here, the $3^{\text {rd }}$ person ergative marker ' $u$ - suggests a verbal noun derived by means of the $-a j$ suffix which operates on transitive verbal roots (Lacadena 2004: 178). An alternative interpretation is that it is a perfect form with the suffix $-V j$. Such perfect forms are widely attested in secondary clauses and frequently supplied with the clitic -iiy: $y$-ilaaj "as X saw it", $y$-itaaj "as X accompanied him", 'u-kab'jiiy "as X ordered it", $y$-a 'ljiiy "as X said it", etc. Thus, we can interpret this phrase either as "it is the calling of 'Ukit Kan Le ' $k$ " or as "being called by 'Ukit Kan Le 'k'. 'Ukit Kan Le'k

Stephen Houston (2014) identified the "Maguey Head" sign as a syllable chi and suggested the reading hu-chi. 
was the ruler of Ek' Balam and, in all likelihood, he summoned ' $U$ Kan Tzimaah to attend an important event. A similar 'u-pe-ka has been recently identified on the travertine vase in the Popol Vuh Museum at the Francisco Marroquín University, Guatemala (Luin et al. in press). The collocation appears at the end of the text: 'u-pe-ka wi-WINAK, 'u-peka[j] winaak, "this was the calling of the man (men)" or "as it was called by the man (men)".

Dütting and Grube (Dütting and Johnson 1993: 189) noticed that the "Rabbit Head" sign appears in the caption for the woman seduced by the Old God on a Codexstyle vase (K5164). They interpreted the caption as na tzak-ah ko-l(o) "the mother is captured (by) the released Old God". Later, Stephen Houston and David Stuart reconsidered this example as the name of the woman (Stuart et al. 1999: II-52). Their reading 'Ix Tzak Kotz'om Chan (Figure 3a) was based on the accompanying scene, where the mythic serpent enrolls the woman, cf. Yukatek kotz' "arrollar, enrollar, enroscar" (Barrera 1995: 339). We doubt that kotz'o ' $m$ chan can be translated "rolledup snake" since -o " $m$ is an agentive suffix meaning "one who does X": kayo ' $m$ "fisher", k'ayo 'm "singer", 'ak'no 'm "giver", etc. Therefore kotz'o'm would mean "roller". Moreover, there are no other examples where the "Rabbit Head" sign is used with the reading value tz'o, meanwhile sign T674 was interpreted as tz'o in several contexts (Davletshin 2001). We apply the pe reading and relate the resulting word ko-pe-ma, kope ' $m$, to the Yukatec verb stem kop- (transitive verb) "to roll, twist, screw", (positional verb) "to fold oneself up, curl or twist self", kopb 'a "arrollarse, enroscarse por sí mismo como la víbora // to coil up (a snake)" (Barrera 1995:

a

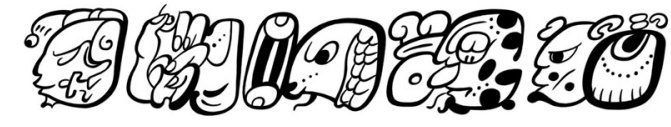

b
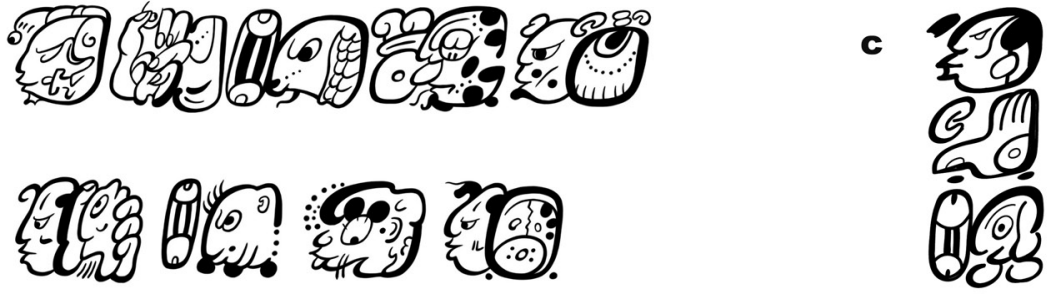

d

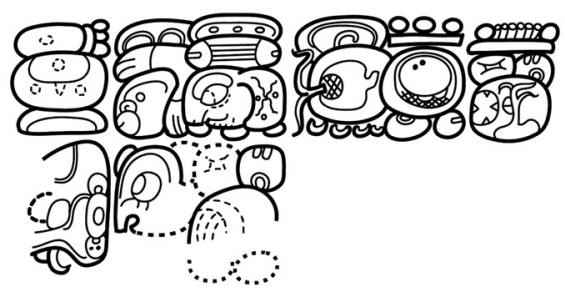

e
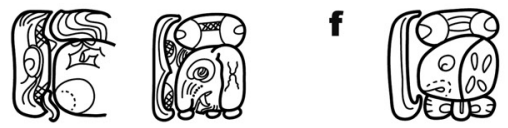

Figure 3. The spelling ko-"Rabbit"-ma: a) woman's name 'IX(IK) TZAK-ja ko-"Rabbit" SAK-CHAN 'IX(IK)+WAY-ya-b'a on Vase K1382; b) woman's name 'IX(IK)-TZAK ko-"Rabbit"-ma CHAN 'IX(IK)-WAY+b'i on Vase K5164; c) 'IX-TZAK? ko-"Rabbit"ma on K2067; d) passage from the text on Panel 19 from Dos Pilas; e) "child of father" parentage statement on Monument 6 from Tortuguero, H1-G2; f) Xcalumkin Miscellaneous Text 5, C. Drawings by Philippe Galeev (a-b) and Albert Davletshin (c-f): after photographs

by Justin Kerr (a-c), photographs of the "Atlas Epigráfico de Petén” Project (d) and photographs by the authors (e-f). 
336-337). Kope ' $m$ could be a perfect participle with the suffix $*_{-} e$ ' $m$ attested as $-e m$ in all Cholan languages. It is usually seen as a perfect participle suffix for the intransitives, but in Modern Ch'orti' the suffix -em is attested with every single root type, transitive as well as intransitive, e.g., kuk-r-em "rolled" from kuk-r- (transitive verb) "to roll over, push over" (Wichmann 1999: 85). The same name accompanied by the same scene is also attested as 'IX TZAK-ja ko-pe SAK-CHAN on vase K1382 and as 'IX-TZAK? ko-pe-ma on K2067 (Figure 3b-c). The name can be read and translated as 'Ix Tsahkaj Kope'm (Sak) Chan "She, The Rolled-up (White) Snake was Conjured/Grasped".

In Classic inscriptions the sequence ko-pe-ma also appears as a noun in the possessed form 'u-ko-pe-ma (Dos Pilas Panel 19, Tortuguero Monument 6, Aguas Calientes Stela 1, Xcalumkin Miscellaneous 5, Edzna Hieroglyphic Stairway 1: p14, see also La Corona Stela 1 and Itzan Stela 17). In Ch'orti' the -em forms may be the objects of prepositions, so they have nominal characteristics even though they also behave as perfective verbs, carrying Set B person markers (Wichmann 1999: 78). This suggests the possibility that the form in -em can be possessed. Stephen Houston pointed out to us that the iconographic controls from Dos Pilas Panel 19 suggest some connection of the spelling to stingray spines and other bloodletting instruments (personal communication, 2001). Indeed, on the partially damaged Panel 19 a prince from Dos Pilas is depicted in a bloodletting ritual (Figure 3d). Drops of blood fall into a basket containing folded paper. A dignitary kneels in front of the prince and holds a stingray spine which was used as ritual implement in bloodletting rituals. We know that under some circumstances, a rope was pulled through the tongue or earlobes for gathering blood and causing pain. The text on the top of the panel starts with the Calendar Round date 9.15.4.16.1 10 Imix 9 Yaxk' in, June 17, 736. The verbal collocation is lost but the following blocks are preserved: K'AK'-...-SAK?-la-li 'u-K'UH-K'AB'A' 'u-ko-pe-ma ...-K'AWIL ch'o-[ko]-?-'AJAW-wa yi-'ILAji-WAXAK-WINAK-wa 'a-'AJAW-TAK-'u-ti-ya [K'IN]-WITZ'-NAL-"Shell Animal'-HA'], K'ahk' ... Saklaal 'u-k'uhul k'ab'a' 'u-kope'm ...-K'awiil ch'ok-?'ajaw y-ilaaj waxak winaak? 'ajawtaak 'uhtiiy K'ihn-Witz'nal-...-Ha', "(something was made with ...-laal, it is the divine name of the kope ' $m$ of ...-K' awiil, the prince of Dos Pilas, as it had been observed by 28 lords; it happened at Dos Pilas". We suggest that here the term kope " $m$ "a rolled-up [object]" could refer to the rope used for drawing blood. Probably, the blood-drawing rope was of such importance for the Maya that these objects were given personal names. The "child of father" parentage statement 'u-ko-pe-ma on Monument 6 from Tortuguero (Figure 3e) can be understood metaphorically: 'u-ni-chi 'u-ko-pe-ma, 'u-nich 'u-kope 'm "his flower, his rolled-up one [bloodletting rope]". Other metaphorical "child of father" parentage expressions which describe the "father" in bloodletting ritual are known: ' $u$-b'aah ch' $a h b$ ' "he is X's penitence/sacrifice" and ' $u$-...k-il y-eh ' $u$-ko(h)kan "he is the offspring (sprout?) on the point of X's stingray spine" (Davletshin 2003). In all likelihood, the spelling 'u-ko-pe-ma functions like a parentage statement on Hieroglyphic Stairway 1 from Edzna, Miscellaneous 5 from Xcalumkin and Stela 1 from Aguas Calientes too (Figure 3f).

The final piece of evidence for the pe reading comes from the name of the socalled "Rabbit Stone" kingdom (Figure 4). The place-name was identified as a small polity related to Piedras Negras by David Stuart and Stephen Houston (Stuart and Houston 1994: 37, 40, Fig. 42). They proposed T'ultuun as a possible reading. 
Later, it was identified by John Montgomery as La Mar (cited in Zender 2002: 177). Simon Martin (2000) discussed Monuments 72 and 84 from Tonina, where the captive Chan Ma's was called 'AJ-"Rabbit Head"-'e-[TUN] 'Aj-...-[tuun] "He from Rabbit stone". The spelling "Rabbit Head"-'e TUN-ni-'AJAW-wa also appears on Monument 91 as a title of a certain Nikte' Mo ' defeated by Tonina. The same name appears as the name of the "Rabbit Stone" lord on the Brussels Panel mentioned above, and there are good reasons to believe that this is the same person. Another example of the "Rabbit Head"-'e-TUN-ni spelling on Panel 4 from Piedras Negras was identified by Simon Martin (Tokovinine 2013: 80, Fig. 46d).

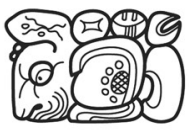

2

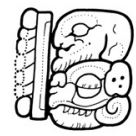

b

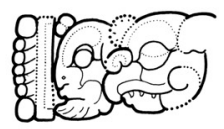

C

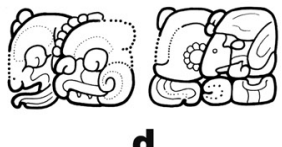

d

Figure 4. Spellings of the so-called "Rabbit Stone" kingdom: a) 2"Rabbit"-TUN-ni'AJAW-wa on Piedras Negras Throne 1; b) 'a-"Rabbit"-'e on Tonina Monument 72, B2;

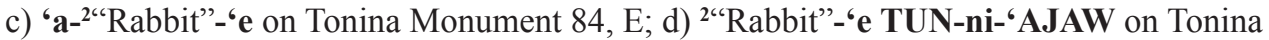
Monument 91, pD-pE. Drawings by Albert Davletshin after photographs by the authors (a) and drawings by Alexander Safronov (b-d).

The only explanation of the parallel forms "Rabbit Head"-TUN-ni and "Rabbit Head"-'e-TUN-ni is that the syllable 'e spells a glottal stop. In this case, the "Rabbit Head" sign should be a syllable consisting in a consonant and the $e$ vowel. The phonetic reading pe satisfies these requirements. The name of the kingdom would be $P e$ 'tuun. This spelling variation can be compared to the word yo "nal that appears in the royal name of Yokib' kings and is also attested in two variants, in one of which the word-internal glottal stop is underspelt: yo-NAL and yo-' $\mathbf{0}-\mathbf{N A L}$. As Søren Wichmann (personal communication, 2002) has suggested to us, the words pe ' and pee " mean "corral, fence" in Akateko, Ixil, Mocho, Q'anjob'al, and Teko, so the place-name Pe "tuun can be interpreted as "Fenced Stone" or "Stone Fence". The gloss under discussion is not attested in Cholan languages and can be interpreted as dialectal.

Nevertheless, the doubler sign "two dots" is attested on the upper left corner in at least three spellings of the "Rabbit Stone" place-name (Figure 4a, c and d). In at least one example, the doubler is missing (the Saktz' $i^{\prime}$ panel from the Royal Art Museum in Brussels). It is a diacritical sign used to indicate that a nearby sign is meant to be read twice; sometimes a syllabic sign is meant to be read twice though the doubler is omitted (Harris 1993: IX; Stuart and Houston 1994: 46). These "two dots" are never attested in combination with the "Rabbit Head" sign in other context, so it is not a part of the graphic design. These facts strongly suggest that the reading of the "Rabbit Stone" place-name is pepe "tuun (see also Martin 2020: 271, 420). Although we have been unable to a word pepe ' in dictionaries of Mayan languages the external form of the word resembles a loan from Zoquean languages and a few loans from these languages are attested in the region (Lacadena and Wichmann 2005: 46), see proto-Mixe-Zoquean *supeepe, Chiapas Zoque pepe " "butterfly" (Wichmann 1995) and proto-Mayan *pehpen "butterfly" (Kaufman and Justeson 2003: 669). 
Not all the glyphic sequences that include the "Rabbit Head" sign can be translated. Two examples from Copan and La Corona probably represent the same verb of an unclear meaning (Figure 5). Temple 11 at Copan contains a long inscription from Yax Pasaj Chan Yopaat's reign (766-ca. 810) that mentions several local deities (Schele et al. 1989: 15, Fig. 13). The text ends on the South Panel of the West Door with an event dated to 9.17.0.0.16 3 Kib' 9 Pop (February 5, 771): (B5) 'u-pe-ja (A6) k'u-yu-T533-ki (B6) 'a-'AJAW-wa (C1) MO'-WITZ-'AJAW (C2) tu-ku-nu (C3) wi-tzi-'AJAW (C4) ha-'o-b'o (C5) ko-ko-no-ma (C6) HUX-wi-ti-ki, 'u-peja[j] K'uy ...k 'Ajaw Mo' Witz 'Ajaw Tukun Witz 'Ajaw ha 'ob' kohkno'm Huux Wi[n] tik, "it is the X-ing of K'uy ...k 'Ajaw, Mo' Witz 'Ajaw Tukun Witz 'Ajaw; they are the guardians of Huux Wintik (Copan)". The spelling 'u-pe-ja might represent a verbal noun derived by means of the $-a j$ suffix, see above Ek' Balam. The same root might be recorded on Panel 1 from La Corona (Stuart et al. 2015: 5, Fig. 5): (H5) 'u-pe-ji-ji (G6) KALOMTE'-TE' (H6) yu-ku-CH'EN-na, 'u-pejij kalo 'mte' Yuk[no 'm] Ch'ee' $n$. This event dated to 9.12.1.6.19 2 Kawak 2 K'ank'in (November 9, 673) occurred six days after a La Corona prince had arrived at Calakmul. Stephen Houston suggested that "this expression is a nominalization in which, by expected phonological process, the $-k$ of peh $k$ has been assimilated to its suffixes" (Houston 2014). However, this phonological process is not attested in Cholan languages, and the syllable ji seems to be doubled with an implication that the root of the verb is not pek-, but pej-.

a
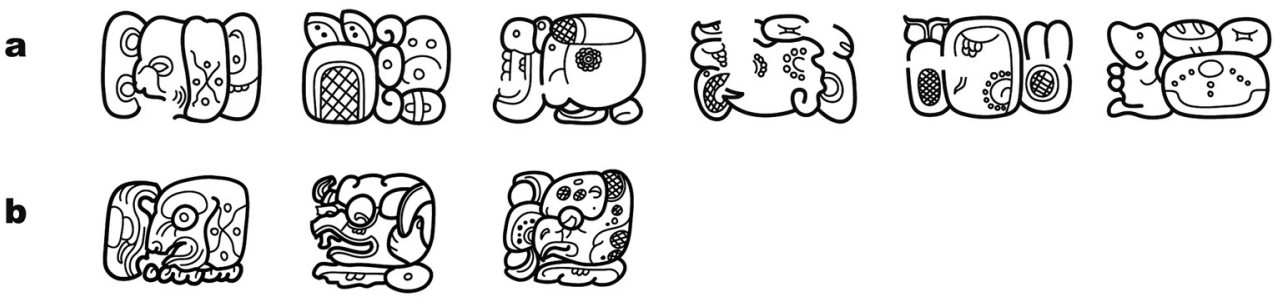

Figure 5. The spellings 'u-"Rabbit"-ja and 'u-"Rabbit"-ji: a) passage in the text on the South Panel of the West Door from Temple 11 in Copan, B5-C3; b) Panel 1 from La Corona, H5-6. Drawings by Albert Davletshin after a drawing of Linda Schele (a) and photographs (b).

Interestingly, the "Rabbit Head" sign possesses other reading values in Maya hieroglyphic inscriptions. One of them is T'UL, "rabbit". It is attested on the "Regal Rabbit" vessel (K1398, see Beliaev and Davletshin 2006) and on Piedras Negras Panel 3 in the name of the Yokib' prince T'uhl Chi 'k (Beliaev and Safronov 2013: 543, 547-548). Another logographic reading of the sign under discussion CHIT was identified by David Stuart on the basis of a syllabic substitution and many examples of final phonetic complements ta and ti (Stuart et al. 1999: II, 56). Its lexical reading is unknown. Polyvalent signs, that is, signs which possess more than one reading value, are relatively rare in Maya hieroglyphic writing. Nevertheless, in the case of the "Rabbit Head" sign it is possible to securely show that it has at least three different reading values -one syllabic reading pe and two logographic ones T'UL, "rabbit", and CHIT, "?". It is unclear how the image of the rabbit head is related 
to the syllable pe, but its attestation in Diego de Landa's alphabet and as a part of three syllabic spellings pe-ka-ja, ( $\left.{ }^{2}\right)$ pe-('e)-TUN-ni and ko-pe-ma leave no room for doubt that the phonetic reading of the sign has been established correctly.

\section{Broader implications}

The identification of the pe syllable and several examples of the verb pehkaj, "he was called", bear important implications for our understanding of Classic Maya political organization.

The convocation by the victorious king of Saktz' $i$ ' in 693 seems to have been a significative event for the history of the kingdom. According to later texts, Saktz' $i$ ' kings adopted the title of "divine kings of ' $A$ ' $e$ "' around this time; their original title had not included the qualifier $k$ 'uhul "divine". We believe that seven placenames mentioned in the inscription were secondary towns subordinated to ' $A k$ ' $e$ '. The convocation of their rulers by $K^{\prime} a b^{\prime}$ 'Chante ' might have been part of wider activities aimed at unification of Saktz' $i$ ' and 'Ak' $e$ ' and creation of the new polity. The relational noun $y$-ichnal "in his proximity, in front of him" implies that new subordinates were physically present to swear fealty for their new overlord.

The summoning of the incense scatterer and portraitist Huuch and the person from Bonampak (see above) can be interpreted in the same way. It took place on March 9, 643 (9.10.10.4.16 $5 \mathrm{~K}$ 'an 9 Pop), exactly 80 days before the Bonampak king Winakhaab' Too ' $k$ ' acceded to the throne under the aegis of the Yaxchilan high king Yaxuun B'ahlam (9.10.10.8.16 7 Kib' 9 Sek, May 28, 643). The coronation took place neither at Bonampak nor at Lacanja but in an unknown place called "Conch Stone". The composite title ch'ajo'm 'a 'naab' "incense scatterer and portraitist" belonged to the noble lords of Xukalnaah. Huuch and his companion came to express their loyalty to the overlord who had installed their new ruler.

Stephen Houston compared pehkaj events to European parliaments and royal summons where "people assembled to talk, negotiate, advise, hear, and obey" (Houston 2014). We believe that a better, Mesoamerican comparison can be drawn. The socalled llamamiento, Spanish "convocation, calling, appeal", was an important concept of the political lexicon in the Postclassic Central Mexico. Charles Gibson (1956; 1964) noticed that the term is not attested in European documents of the $15^{\text {th }}$ and $16^{\text {th }}$ centuries and suggested that the llamamiento general in the Acolhua region was of Pre-Columbian origin. Gibson (1956: 2) gives an example from Fernando de Alva Ixtlilxochitl's works who described the construction of the palace of Nezahualcoyotl by the subjects of the Triple Alliance and observed that the work had been performed by the three capital cities "con todos sus llamamientos" (Spanish, "with all their callings"). Gibson concluded that the word llamamiento is to be understood in the meaning of convocation, specifically for labor, or to the region occupied by the workers under the authority of an individual official or town. Later, he associated llamamiento with labor summons (Gibson 1964: 137). Unfortunately, we were unable to identify the original terms for llamamiento and llamamiento general in Classical Nahuatl.

The llamamiento institute was not limited to the Central Mexico. Early Colonial documents from the Chontal-speaking area of Acalan, "Documentos Maldonado Paxbolon", use the term < upayolel $>$ in a very similar sense. This is based on the root pay- "to call, pray", cf. proto-Cholan *pay "llamar // to call; invitar, convidar 
// invite" (Kaufman and Norman 1984: 128). In the parallel Spanish text, the term is translated as "jurisdiction" and "region" as can be seen from the following two examples: < vi ta cah ukaua Santa Maria Tixchel upayolel ukabal uillayl San fransisco canpeche tuprovinciail yucatan>, "En el puevlo que se llama Santa Maria de Tichel en la jurisdiccion y tierra de la villa de San Fransisco de Capmeche provincia de Yucatan", and <upayolel uvincilel ytztapannecatob>, "Ésta era la región y la gente de Itztapan" (Smailus 1975: 24, 30).

The comparison of pehkaj events of Maya texts with the Central Mexican llamamiento allows us to reconsider interpretation of the titles of origin in Classic Maya texts. Stuart and Houston demonstrated that they are based on the place-names and can follow Emblem Glyphs (Stuart and Houston 1994: 33-37). Since then, it has been generally accepted that these titles indicate the place of origin of individuals and used for referring to secondary lords. To give an example, provincial governors from the Pakbu'l kingdom are recorded by their respective titles of origins on Piedras Negras Stela 12. New evidence suggest that the titles of origin can refer to groups of people.

Recently, Marc Zender (2019: 33) has analyzed a passage in the text on La Corona Element 56: KAJ-yi-'AK-TUN-ni HUL-sa-ni-'AJ-SAK-NIK-TE', kajaay 'Ahktuun hulsaan 'Aj-Saknikte', "Ahktuun was established (and) he brought people there, (namely) those of Saknikte". His interpretation assumes that the title of origin 'Aj-Saknikte' refers to a group of people in this context. Recently too, Sergei Vepretskii has reinterpreted the closing passage on Hieroglyphic Stairway Step 6 from Naranjo with the idea that a title of origin refers to a group of people: [yi]ta 3-TE'-TUN-ni 'AJ-chi[ku]-NAB', y-itaaj Huuxte 'tuun 'Aj-Chi 'knaahb', "he was accompanied by people from Calakmul" (cf. Tokovinine 2007: 19-21; Helmke and Vepretskii 2019).

The interpretation "a group of people from such and such place" also makes more sense in the texts with pehkaj events discussed above. The passage on the Denver and Brussels panels can be translate as "Yab' $a \ldots l$, he from $K$ 'ante ' $l$, people from

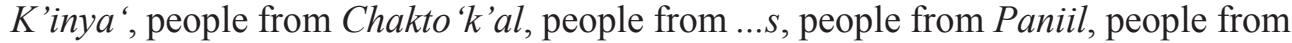
'Atuun, and people from 'Ab'u' $a$ ' (all) were convoked". The same works for the passage from Bonampak Sculptured Stone 5: "the incense scatterer and portraitist Huuch and people from Bonampak were called before Yaxuun B'ahlam, the king of Yaxchilan". In these cases, the titles of origin might not refer to the nobles as such but to larger social bodies of the corresponding communities, prominent lineages, heads of corporate groups, traders, warriors and others. This context also suggests the translation "representative of such and such place".

In the Postclassic and Early Colonial Central Mexico llamamiento was a form of organization of corvee labor. This makes us believe that designations of broader social groups in the context of pehkaj events indicate prestation of labor service and that these callings were an important coercion mechanism of Classic Maya politics.

ACKNowledgements: We would like to thank Alexandre Tokovinine, Alfonso Lacadena, Christian Prager, Søren Wichmann and Stephen Houston for their comments on a preliminary version of this note distributed in 2001. We are grateful to Søren Wichmann for his revision of the original draft of this paper and to Alexander Safronov, Philippe Galeev and Sergei Vepretskii for their help in preparation of the final version. Dmitri Beliaev's research was supported by the Russian Science Foundation (Project \# 18-18-00454, https://rscf.ru/project/18-18-00454/). 


\section{References}

Barrera Vásquez, Alfredo. 1995. Diccionario maya. Maya-español, español-maya. $3^{\text {rd }}$ edition. México: Porrua.

Beliaev, Dmitri. 2004. "Wayaab’ Title in Maya Hieroglyphic Inscriptions: On the Problem of Religious Specialization in Classic Maya Society", in Maya Religious Practices: Processes of Change and Adaptation, Daniel Graña Behrens, Nikolai Grube, Christian Prager, Frauke Sachse, Stefanie Teufel and Elisabeth Wagner, eds., pp. 121-130. Acta Mesoamericana 14. Markt Schwaben: Verlag Anton Saurwein.

Beliaev, Dmitri and Albert Davletshin. 2006. "Los sujetos novelísticos y las palabras obscenas: Los mitos, los cuentos y las anécdotas en los textos mayas sobre la cerámica del período clásico", in Sacred Books, Sacred Languages: Two Thousand Years of Religious and Ritual Mayan Literature. Proceedings of the 8th European Maya Conference Madrid, November 25 - 30, 2003, Rogelio Valencia Rivera and Geneviève LeFort, eds., pp. 21-44. Acta Mesoamericana 18. Markt Schwaben: Verlag Anton Saurwein.

Beliaev, Dmitri and Alexander Safronov. 2004. “Ак’е и Шукальнах: История и политическая география государств майя Верхней Усумасинты (Ak’e and Shukalnah: History and Political Geography of the Maya states in the Upper Usumacinta)", in Древний Восток и античный мир. Труды кафедры истории древнего мира исторического факультета МГУ (Ancient East and Antiquity. Works of the Department of the Ancient World, Faculty of History, Lomonosov Moscow State University), vol. 6, pp. 119-142. Moscow: Akademika.

—. 2013. “Династическая история Йокиба второй половины VIII века (Dynastic History of Yokib in the Second Half of the 8th Century, in Russian)", in Вопросы эпиграфики (Issues in Epigraphy) 7(1), Alexander Avdeev, ed., pp. 533-599. Moscow: Russian Foundation for the Advancement of the Education and Science.

Bricker, Victoria R. 1986. A Grammar of Maya Hieroglyphs. Middle American Research Institute, Publication 56. New Orleans: Tulane University.

Davletshin, Albert. 2001. "Possible Reading of T674 Syllable". Unpublished research note circulated among epigraphers.

—. 2003. "Glyph for Stingray Spine". Mesoweb. http://www.mesoweb.com/features/davletshin/ Spine.pdf.

Diehr, Franziska, Sven Gronemeyer, Elisabeth Wagner, Christian Prager, Katja Diederichs, Uwe Sikora, Maximilian Brodhun and Nikolai Grube. 2018. "Modelling vagueness - A criteria-based system for the qualitative assessment of reading proposals for the deciphering of Classic Mayan hieroglyphs", in Proceedings of the Workshop on Computational Methods in the Humanities 2018 (COMHUM 2018), Université de Lausanne, June 4-5, 2018, Michael Piotrowski ed., pp. 33-44. Lausanne: Université de Lausanne.

Dütting, Dieter and Richard Johnson. 1993. "The Regal Rabbit, the Night Sun and God L: An analysis of iconography and texts on a Classic Maya vase". Baessler-Archiv, Neue Folge XLI: $167-205$.

Gibson, Charles. 1956. "Llamamiento General, Repartimiento, and the Empire of Acolhuacan". The Hispanic American Historical Review 36: 1-27.

-. 1964. "The Pre-Conquest Tepanec Zone and the Labor Drafts of the Sixteenth Century". Revista de Historia de América 57/58: 136-145.

Golden, Charles, Andrew K. Scherer, Stephen Houston, Whittaker Schroder, Shanti Morell-Hart, Socorro del Pilar Jiménez Álvarez, George Van Kollias, Moises Yerath Ramiro Talavera, Mallory Matsumoto, Jeffrey Dobereiner and Omar Alcover Firpi. 2020. "Centering the Classic Maya Kingdom of Sak Tz'i'”. Journal of Field Archaeology 45 (2): 67-85. 
Grube, Nikolai. 1998. "Die Entzifferung der Maya-Handschriften”, in Die Bücher der Maya, Mixteken und Azteken: die Schrift und ihre Funktion in vorspanischen und kolonialen Codices, Carmen Arellano Hoffmann and Peter Schmidt, eds., pp. 67-101. Frankfurt am Main: Vervuert.

Harris, John F. 1993. New and Recent Maya Hieroglyph Readings. Philadelphia: The University Museum.

Helmke, Christophe and Sergei Vepretskii. 2019. “Todo está, todo es aquí: un relato de los reyes de Kanu'l inscrito en la escalinata jeroglífica de K'an II de Caracol". Paper presented at the XI Congreso Internacional de Mayistas "Tradiciones y reelaboraciones". Universidad Nacional Autónoma de México, Chetumal, Universidad de Quintana Roo, June 23-29, 2019.

Houston, Stephen. 2014. "Pehk and Parliaments". Maya Decipherment: Ideas on Ancient Maya Writing and Iconography, October 7. https://decipherment.wordpress.com/ 2014/10/07/pehk-and-parliaments/.

Houston, Stephen and Simon Martin. 2016. "Through seeing stones: Maya epigraphy as a mature discipline". Antiquity 90, 350: 443-455. https://doi.org/10.15184/aqy.2016.33.

Houston, Stephen, David Stuart and John Robertson. 1998. "Disharmony in Maya Hieroglyphic Writing: Linguistic Change and Continuity in Classic Society", in Anatomía de una civilización: Aproximaciones interdisciplinarias a la Cultura Maya, Andrés Ciudad Ruiz et al., eds., pp. 275-296. Publicaciones de la SEEM 4. Madrid: Sociedad Española de Estudios Mayas.

Houston, Stephen, David Stuart and Marc Zender. 2017. "The Lizard King". Maya Decipherment: Ideas on Ancient Maya Writing and Iconography, June 15. https:// mayadecipherment.com/2017/06/15/the-lizard-king/.

Hull, Kerry. 2000. "Cosmological and Ritual Language in Ch'orti"“. Report to the Foundation for the Advancement of Mesoamerican Studies (FAMSI). http://www.famsi. org/reports/99036/99036Hull01.pdf.

Kaufman, Terrence and John S. Justeson. 2003. "A Preliminary Mayan Etymological Dictionary". Report to the Foundation for the Advancement of Mesoamerican Studies (FAMSI). http://www.famsi.org/reports/01051/pmed.pdf.

Kaufman, Terrence S. and William M. Norman. 1984. “An Outline of Proto-Cholan Phonology, Morphology and Vocabulary", in Phoneticism in Mayan Hieroglyphic Writing, John S. Justeson and Lyle R. Campbell, eds., pp. 77-166. Institute for Mesoamerican Studies Monograph 9. Albany: State University of New York at Albany.

Knorozov, Yuriy V. 1952. "Drevniaia Pis'mennost' Tsentral'noi Ameriki [The Ancient Writing of Central America]". Sovietskaya Etnografiya 3: 100-118.

Knorozov, Yuri and Galina Ershova. 1994. "Diego de Landa como fundador del estudio de la cultura maya". Anales del Museo de América 2: 21-32.

Lacadena, Alfonso. 2003. "El corpus glífico de Ek’ Balam, Yucatán, México”, Report to the Foundation for the Advancement of Mesoamerican Studies (FAMSI). http://www.famsi. org/reports/01057es/01057esLacadenaGarciaGallo01.pdf

-. 2004. "Passive Voice in Classic Mayan Texts: CV- $h$-C- $a j$ and $-n-a j$ constructions", in The Linguistics of Maya Writing, Søren Wichmann, ed., pp. 165-194. Salt Lake City: The University of Utah Press.

Lacadena, Alfonso and Søren Wichmann. 2004. "On the Representation of the Glottal Stop in Maya Writing”, in The Linguistics of Maya Writing, Søren Wichmann, ed., pp. 103-162. Salt Lake City: The University of Utah Press. 
-. 2005. "The Dynamics of Language in the Western Lowland Maya Region", in Arts for Archaeology's Sake: Material Culture and Style across the Disciplines, Andrea WattersRist, Christine Cluney, Calla McNamee and Larry Steinbrenner, eds., pp. 32-48. Calgary: University of Calgary Press.

—. 2019. "Harmony Rules and the Suffix Domain: A Study of Maya Scribal Conventions". Revista Española de Antropología Americana 49 Número Especial: 183-208. https://doi. org/10.5209/reaa.64966.

Luin, Camilo, Dmitri Beliaev and Sergei Vepretskii. In press. "La vasija de alabastro del Museo Popol Vuh". Paper presented at the XXXIV Simposio de Investigaciones Arqueológicas en Guatemala, 2021. Guatemala: Museo Nacional de Arqueología y Etnología.

Martin, Simon. 2000. "New Monuments in the Tonina Museum”. Unpublished MS.

-. 2020. Ancient Maya Politics: A Political Anthropology of the Classic Period, 150-900 $C E$. New York: Cambridge University Press.

Matsumoto, Mallory and Nicholas Carter. 2020. "Recent Developments in Maya Epigraphic Research", in The Maya World, Scott R. Hutson and Traci Ardren, eds., pp. 599-623. London and New York: Routledge.

Prager, Christian. 2021. "Visual dimensions of Maya hieroglyphic writing: meanings beyond the surface", in The Social and Cultural Contexts of Historic Writing Practices, Philip J. Boyes, Philippa M. Steele and Natalia Elvira Astoreca, eds., pp. 101-124. Oxford and Philadelphia: Oxbow Books.

Schele, Linda and Nikolai Grube. 1995. Notebook for the XIXth Maya Hieroglyphic Workshop at Texas. Texas: University of Austin.

-. 1997. Workbook for the Maya Hieroglyphic Workshop: The Dresden Codex. Austin: University of Texas.

Schele, Linda, David Stuart and Nikolai Grube. 1989. "A Commentary on the Restoration and Reading of the Glyphic Panels from Temple 11". Copan Notes 64: 1-19.

Smailus, Ortwin. 1975. El maya-chontal de Acalán. Análisis lingüístico de un documento de los años 1610-12. México: Centro de Estudios Mayas, Instituto de Investigaciones Filológicas, Universidad Nacional Autónoma de México.

Stone, Andrea and Marc U. Zender. 2011. Reading Maya Art: A Hieroglyphic Guide to Ancient Maya Painting and Sculpture. London: Thames and Hudson.

Stuart, David. 2008. "Unusual Signs 1: A Possible Co Syllable”. Maya Decipherment: Ideas on Ancient Maya Writing and Iconography, September 13. https://mayadecipherment. com/2008/09/13/unusual-signs-1-a-possible-co-syllable/.

Stuart, David and Stephen Houston. 1994. Classic Maya Place Names. Studies in PreColumbian Art and Archaeology No. 33. Washington: Dumbarton Oaks Research Library and Collection.

Stuart, David, Stephen Houston and John Robertson. 1999. "Recovering the Past: Classic Maya Language and Classic Maya gods", in Notebook for the XXIIIrd Maya Hieroglyphic Forum at Texas, pp. II: 1-80. Austin: University of Texas.

Stuart, David, Marcello A. Canuto and Tomás Barrientos Quezada. 2015. "The Nomenclature of La Corona Sculpture". La Corona Notes 1 (2). http://www.mesoweb.com/LaCorona/ LaCoronaNotes02.pdf.

Stuart, David, Marcello A. Canuto, Tomás Barrientos Quezada and Maxime Lamoureax St-Hillaire. 2015. "Preliminary Notes on Two Recently Discovered Inscriptions from La Corona, Guatemala". Maya Decipherment: Ideas on Ancient Maya Writing and Iconography, July 17. https://mayadecipherment.com/2015/07/. 
Thompson, John Eric S. 1962. A Catalog of Maya Hieroglyphs. Norman: University of Oklahoma Press.

Tokovinine, Alexandre. 2007. "Of Snake Kings and Cannibals: A Fresh Look at the Naranjo Hieroglyphic Stairway”. The PARI Journal 7 (4): 15-22. https://www.precolumbia.org/ pari/journal/archive/PARI0704.pdf.

-. 2013. Place and Identity in Classic Maya Narratives. Washington, D.C.: Dumbarton Oaks Research Library and Collection.

Wichmann, Søren. 1995. The Relationship among the Mixe-Zoquean languages of Mexico. Salt Lake City: University of Utah Press.

- 1999. A Ch'orti 'Morphological Sketch. Unpublished MS., Department of History of Religions, University of Copenhagen.

Zender, Marc U. 2002. "The Toponyms of El Cayo, Piedras Negras, and La Mar", in Heart of Creation: The Mesoamerican World and the Legacy of Linda Schele, Andrea Stone, ed., pp. 166-184. Tuscaloosa: University of Alabama Press.

—. 2017. "Theory and Method in Maya Decipherment". The PARI Journal 18 (2): 1-48. https://www.precolumbia.org/pari/journal/archive/PARI1802.pdf.

—. 2019. "The Classic Mayan Causative". The PARI Journal 20 (2): 28-40. https://www. precolumbia.org/pari/journal/archive/PARI2002.pdf.

Zender, Marc U., Dmitri Beliaev and Albert Davletshin. 2016. "The Syllabic Sign we and an Apologia for Delayed Decipherment". The PARI Journal 17 (2): 33-56. https://www. precolumbia.org/pari/journal/archive/PARI1702.pdf. 
